\title{
The Role of Financial Inclusion on Economic Growth: Theoretical and Empirical Literature Review Analysis
}

Hamad Omar Bakar and Zunaidah Sulong*

Faculty of Economics and Management Sciences, Universiti Sultan Zainal Abidin, Gong Badak Campus, Malaysia

\begin{abstract}
Recently, the direction of policy maker's shifted from financial development to financial inclusion in enhancing sustainable economic growth especially to developing countries. However, the argument as to whether financial inclusion utilize positive impact on generating growth economy still remains uncertain due to contrasting results found on the literature. This paper describes the effect of financial inclusion into direction as its effect on growth as to whether it is positive, negative, it's transmission channels and causality effect. The optimistic views for financial inclusion on growth, based on the accessibility of financial services includes; expansion of bank branches, minimizing a barrier in access to finance and contribution of banking sector. On other hand, those studies that confirmed negative or weak contribution of financial inclusion on growth is due to weak financial system, low availability of financial system. It is suggested that, using a multidimensional variable is more preferable in order to observe better assessment of the effect of financial inclusion on growth.
\end{abstract}

Keywords: Financial inclusion; Economic growth; Financial system

\section{Introduction}

\section{Theoretical literature of financial inclusion on economic growth}

Financial inclusion becomes a major phenomenon for policy maker across the world for planning a strong policy in achieving the sustainable growth. In a theoretical perspective, it has been argued that, financial inclusion is a drive forces toward economic growth. The earlier approach by Schumpeter has been demonstrated that finance boost growth [1]. According to this approach, financial sector via its services not only help for the accessibility of capital formation but also encourage innovation, efficiency and investment which in turn growth output. In line to growth in economy, banking sector seems to be more specified and cost effective since it encourages capital accumulation and attract business competition among the banks which result the more investment and growth as a whole.

In supporting the Schumpeter approach, King and Levine demonstrated the evidence that, banking sector as a major financial intermediation have a strong long run growth and productivity via capital accumulation [1,2]. However, there is a variation of financial system in its performance due to time, geographical areas and also difference dimensions [3,4]. Moreover, the earlier study by Robinson illustrated that, it is not always compulsory that, the link between finance and growth to observe the similar outcome in all situations and that, some circumstances results in unidirectional relation [5]. On other hand, Levine introduces capital accumulation and technological changes as channels via financial system which affect growth.

In addition to that, Schumpeter approach has been supported by Goldsmith, McKinnon and Shaw who highlighted that, financial system plays a positive role toward economic growth $[1,6,7]$. These approaches rely on financial market determination to set interest rate and increase demand for financial services which further develop competition among the banks and ensuring the rise of saving rate and investment and economy.

Boyd and Prescott, Diamond and Aghion et al. claimed that, financial markets accelerate saving and investment which then results in economic growth [8-10]. Therefore, from these particular approaches, the improvement of financial market stands as a key image toward growth economy. While in some of policy especially for financial liberalization shows failure to improve finance on growth output. However, in general many theories have argued that there is a positive link between finance and growth including Fry, Hicks and Thakor [11-13].

In general, this paper includes eight main sections, Introduction part which includes theoretical effect of financial inclusion on growth. Furthermore, it provides empirical literatures into different sections includes, Positive effect on Panel and Cross Section studies, Positive effect on Time Series and individual country literatures, negative effect, Causality effect and it's Growth Enhancing Transmission channels and it ends with Conclusion part.

\section{Empirical reviews of the impact of inclusion on economic growth}

In recent years, the policy has been shifted direction of financial system. The direction shifted from financial development to financial inclusion [14]. From this fact, few of empirical works related on the role of financial Inclusion on growth economy has been discussed and received extensive attention. Most of the empirical work has been done on developed economy and left developing economy with limited literature in this field. According to Park \& Merrcado, Jr., financial inclusion in developing economy is still in infant stage [15].

However, the argument as to whether financial inclusion utilize positive impact on generating growth economy still remains uncertain due to contrasting results found on the literature. However, most of the empirical studies in both individual and cross section confirm

${ }^{*}$ Corresponding author: Zunaidah Sulong, Faculty of Economics and Management Sciences, Universiti Sultan Zainal Abidin, Gong Badak Campus, Malaysia, Tel: 6096688253; E-mail: zunaidahzs@gmail.com

Received September 24, 2018; Accepted October 31, 2018; Published November 06, 2018

Citation: Sulong Z, Bakar HO (2018) The Role of Financial Inclusion on Economic Growth: Theoretical and Empirical Literature Review Analysis. J Bus Fin Aff 7: 356 doi: 10.4172/2167-0234.1000356

Copyright: $\odot 2018$ Bakar HO, et al. This is an open-access article distributed under the terms of the Creative Commons Attribution License, which permits unrestricted use, distribution, and reproduction in any medium, provided the original author and source are credited. 
positive effect while few studies do not support this notation. The positive effect however, is categorized into two parts. Firstly, panel and cross section and secondly individual country studies (panel and time series). Moreover, some studies looked on mediating effect of financial inclusion on growth. They suggested that, financial inclusion is good for growth effect when it interact with other channels including mobile penetration and gender dimension. Hence this study describes the literature review on the effect of financial inclusion and its mediating effect on growth.

\section{Positive Effect on Panel and Cross Section Studies}

While policy makers in different countries pay a high attention on effect of financial development on economy, empirical studies looking for financial inclusion have not received much attention. It is therefore only a few studies have been explored in this field. However, several panel and cross section studies that have been examined, recommended that financial inclusion spur a positive effect on growth economy which denotes that financial inclusion is an engine toward generating economic growth. These studies employed various approach to demonstrate the positive effect including Generalized Method of Moment (GMM), Autoregressive Distributed Lag (ARDL), VAR regression and Ordinary Least Square (OLS). These includes Andrianaivo and Kpodar [16], Inoue and Hamori [17], Balach R et al. [18], Kim [19], Kim et al. [20] and Pradhan et al. [21]. According to their results, financial inclusion plays a vital role in rising a strong and well-organized the structure of financial system which enhances the growth rate of economy. In this section the review of the literature based on the evidence from cross section and panel studies.

Andrianaivo and Kpodar [16] using GMM approach investigated whether financial inclusion spurs growth in a panel of 44 African countries. The results confirmed the positive and significant effect on growth. Additional to that, the results reveals that a well financial sector has positive role on economic growth. Wong [22] demonstrated a positive effect on growth economy for developing nations. Likewise, Inoue and Hamori [17] used the same technique to assess 37 SSA countries in a period (2004-2012). They found that "the commercial bank branches" as an instrument used to measure the effect of financial inclusion on growth has a positive relation for selected countries.

Further results suggested that, the improvement of financial access enhance the growth effect in this region. The recent study by Kim et al. [20] using GMM approach for a period 1990-2013 in a sample of 55 OIC countries demonstrated a positive relation between financial inclusion on growth for OIC countries. Further the results concluded that the high level of financial inclusion is an essential factor toward generating economic growth. In addition to that, Kim for European Union and OECD countries (2004-2011) supports the views revealed by Kim et al. that financial inclusion has a positive effect growth [20]. The effect however become stronger in high fragility countries compared to the countries of low fragility.

Balach R et al. [18] used "commercial bank branches per 100,000 adults and ATMs per 100,000 adults" as a proxies of financial inclusion to assess its effect on growth economy for 97 cross section countries for a period (2004-2012). The results confirmed the positive effect on growth for both proxies. Further, recent study by Sethi and Acharyaa [23] used dynamic OLS (DOLS) and fully modified OLS (FMOLS) to assess the link between financial inclusions on growth for 31 countries and concluded that, financial inclusion encourage growth for these countries.

Subrahmanyam and Acharya [24] argued that, financial inclusion boost growth compared with demand following approach. Likewise, the study by Demirguc and Klapper [25] concluded that, the countries where bank branches as well as deposit are high obviously the income level also increase rapidly. This indicates that, the higher financial inclusion in a given countries boost high growth economy. However, in this study the high number of branches and banking account has been observed more in advanced economy rather than low and middle countries.

\section{Positive Effect on Time Series and Individual Country Literatures}

Similar to that of cross section studies, financial inclusion effect on growth also has been explored in terms of individual countries level. By using various indicators especially in banking institution including commercial bank branches credit and Automatic Teller Machines most of these studies agree that financial inclusion spur growth in given countries [26-31]. Most of these studies used various approach to assess its impact including Ordinary Least Square (OLS), Fully modified least square (FMOLS), Vector auto-regression (VAR) and Autoregressive Distributed Lag (ARDL). For example, Sharma, confirm a positive correlation between various dimension of financial inclusion and economic growth of India during the period of study.

Further study by Babajide et al. [32] in Nigeria, number of commercial Bank branches per $1000 \mathrm{~km}^{2}$ or per 100, 000 adults and commercial bank deposits (CMBD) had significant positive impact to total factor productivity. Lenka and Sharma [33] demonstrated a positive and significant between financial inclusions on growth effect for Indian economy. Dabla-Norris et al. [34] has been used a general equilibrium model to illuminate how lowering monitoring costs, relaxing collateral requirements and thereby increasing firms. The result confirms that, for a high extent access to credit would increase economic growth. Omojolaibi [35] for Nigerian economy (1980-2014) found that the financial inclusion is significant factor for generating per capita GDP and poverty reduction. Aduda and Kalunda [27] supposed that access to finance for household is definitely has a strong positive significant relation with growth. Likewise, Brune et al. [36] highlighted that the rising up of financial inclusion via development in saving account develop the social welfare and wellbeing of poor households.

In addition to that, Angadi [37] has argued that, a well financial infrastructure is largely encouraging economic development. The Angadi [37] result has supported by Neal [38] and North [39] who verified that, more and well financial institutions in a given region has a better opportunity to enjoy economic growth. Likewise, Odedokun [40] demonstrated that in real terms the growth of financial aggregates confirms a positive result on growth in developing nations regardless of the level of economic development. Moreover, Dev [41] claimed that, financial inclusion in India is a strategic way and plays a strong way toward improving the livelihood of poor farmers and rural enterprises alongside with different issues of financial inclusion.

Beck et al., reported that, the rising number of bank branches (one among the indicator of financial inclusion) also generate efficiency among the banks and growth economy as whole [4,42]. Mehrotra et al. highlighted that, the accessibility of banking services to the people; it helps them to deposit their money in the formal financial institutions that in turn rising economic growth via multiplier effect [43]. Khan [44] India and demonstrated that the accessibility on essential financial services boost the economic activities as well as employment opportunities at rural households in India. By using entrepreneurship approach Serrao et al. [45] illustrated that the microfinance has 
contributed the positive effect on consumption and also output. Moreover, Ghosh [46] confirm the social banking experiments have a positive influence on economic of Indian economy. Consistence with earlier work by Beck et al. [42] and Kendall et al. [47] the result further argued that, utilization of financial services and financial outpace determined the per capita growth together with vigorous technological role.

Cumming et al. established the significant of financial access where entrepreneurs are stimulated to take risk and encourage more investment as a result boost the economic growth [48]. Other empirical evidence that confirm positive link between financial inclusion on economic growth with a focus of individual countries includes Swamy, Mohan, Arora, Chattopadhyay, Gupte et al., Dixit and Ghosh [49-54]. The overall argument for the most of these studies emphasizes the accessibility of financial services and product for the majority of society such as adequate credit at reasonable cost especially for poor people, payment system, transfer and deposit services, sound of financial institution and its sustainability in order to ensure the positive effect of financial inclusion on growth effects.

\section{Financial Inclusion has Negative Effect on Growth}

Despite a large number of empirical studies to support the assumption that financial inclusion is good for boosting economic growth, however this assumption could not necessarily to become valid all the time. It is claimed that, weak financial system, inappropriate policy and poor financial instrument obstacles to ensure significant effect of finance on growth. Barajas et al., claimed that, is not necessarily to provide a positive link between financial inclusion on growth for all economic system [55]. From this sense some of the few literatures fail to observe positive effect instead confirmed negative impact between this link. For example, Pearce [56] argued that, even though there is a significant growth in productivity and efficiency yet, inability of the financial system to reach the majority of the population including poor, woman, elders and other disadvantage groups is a major reason behind this argument.

In line with previous studies, Naceur and Samir [57] demonstrated that bank development index' bank and credit to private sector development for MENA countries had a negative effect on economic growth. Likewise, Moore and Craigwell claimed that, the provision of smaller financial products does not produce higher financial return related to the operating finance cost of proving it [58]. The result is related to the current study by Natamba et al. [59].

In a study by Bhattarai [60] discussed that, the world crises took place in 2008 together with over financing has caused the falling of the growth rate in some of the advanced countries such as Germany, France and UK. Though this effect for some of the emerging economy countries including China and India was not affected rather, it maintained their sustainable growth. Moreover, Arestis et al. found sluggish relation between financial deepening and growth [61]. Although there is a variation between the level of development and inflation across countries however some of the countries that found weaken relation has been observed that, the rapid depth of banking system in a given country may discouraged in productive credit that results to rise the inflationary pressures.

\section{Causality Effect between Financial Inclusion and Economic Growth}

Financial inclusion does not end with positive or negative effect on growth; instead the causal relation may exist. For example, Sharma
[29] highlight the existent of unidirectional and bidirectional effect among the "number of deposits/loan accounts and per capita GDP" and secondly bi-directional causality between" geographic outreach and economic development.

Furthermore, Lenk and Sharma [33] over a period (1980-2014) suggested the unidirectional causality between financial inclusion and economic growth. Also, Kim et al. observed that financial inclusion has a mutual panel causality effect with economic growth [20]. Apergis et al. found bi-directional causality between financial deepening and growth in 15 OECD and 50 non-OECD counties [62].

\section{Transmission Channels of Financial Sector on Economic Growth}

The studies looking for mediating effect between financial inclusions on growth is still not much analyzed. However, the few studies that examined demonstrated that some of mediating term including mobile penetration and gender dimension financial inclusions' growth enhancing channels. For example, Andrianaivo and Kpodar determined that, the mediating term between financial inclusion and mobile penetration is positively and significant on economic growth rate of 44 African countries [16]. The same result confirmed by Swamy for gender dimension on growth rate. In these both results suggested that, there is a high influence on growth effect via these channels [63].

\section{Conclusion}

In general, the links between financial inclusions on growth are still inconclusive due to mixed results found in the literature. Despite many studies confirming positive effect on growth, but some studies are contrary, claimed that financial inclusion has negative effect. The optimistic views for financial inclusion on growth, based on the accessibility of financial services includes; expansion of bank branches, minimizing a barrier in access to finance and contribution of banking sector. However, it would be worthwhile to the policy to play their part in increasing the network branches, penetration of financial services and also eradicate all barriers toward accessing financial services in order to ensure economic sustainability derived from financial inclusion.

On other hand, those studies that confirmed negative or weak contribution of financial inclusion on growth is due to weak financial system, low availability of financial system. Meanwhile, policy makers have to encourage the availability of financial system to vast segment of the society in stimulating effect on growth, in a society and the national as whole.

In general, the literature shows that, financial inclusion is an engine toward growth economy in a several dimensions with various methods used to assess this link. However, some of the studies used only one variable to assess to assess the effectiveness of financial inclusion on growth. Since, financial inclusion is a multidimensional process hence using one variable to measure could not give clear information due to the nature of financial inclusion.

It is suggested that, using a multidimensional variable is more preferable in order to observe better assessment of the effect of financial inclusion on growth. Not only that, but also the policy maker has to address appropriate policy toward strengthening financial inclusion in order to generate sustainable economic growth in developing countries. 
Citation: Sulong Z, Bakar HO (2018) The Role of Financial Inclusion on Economic Growth: Theoretical and Empirical Literature Review Analysis. J Bus Fin Aff 7: 356. doi: 10.4172/2167-0234.1000356

\section{References}

1. Schumpeter JA (1911) The Theory of Economic Development: An Inquiry into Profits, Capital, Credit, Interest and the Business Cycle. Harvard University Press, Cambridge.

2. King RG, Levine R (1993) Finance and growth: Schumpeter might be right. Q J Econ 108: 713-737.

3. Honohan P (2004) Financial sector policy and the poor: Selected issues and evidence. World Bank Working Paper, p: 43.

4. Beck T, Demirgüç-Kunt A, Levine R (2007a) Finance, inequality and the poor J Econ Growth 12: 27-49.

5. Robinson $\mathrm{J}$ (1952) The generalization of the general theory. The Rate of Interest and Other Essays. Macmillan, London, pp: 67-146.

6. Goldsmith RW (1969) Financial Structure and Development. New Haven, CT: Yale University Press.

7. Mckinnon RI (1973) Money and Capital in Economic Development. Brookings Institute, Washington Shaw.

8. Boyd JH, Prescott E (1986) Financial intermediary-coalitions. J Econ Theory 38: 211-232.

9. Diamond DW (1984) Financial intermediation and delegated monitoring. Rev Econ Stud 51: 393-414

10. Aghion P, Angeletos G-M, Banerjee A, Manova K (2004) Volatility and growth: The role of financial development. Harvard University.

11. Fry MJ (1978) Money and capital or financial deepening in economic development. J Money Credit Bank 10: 464-475.

12. Hicks J (1969) A Theory of Economic History. Clarendon Press, Oxford.

13. Thakor AV (1996) The design of financial systems: An overview. J Bank Finance 20: 917-948.

14. Johnson S, Arnold S (2012) Inclusive financial markets: is transformation under way in Kenya? Development Policy Review 30: 719-748.

15. Park CY, Mercado Jr (2015) Financial inclusion, Poverty, and income inequality in developing Asia. ADB Economics Working Paper Series.

16. Andrianaivo M, Kpodar K (2011) ICT, Financial Inclusion, and Growth Evidence from African countries. Review of Economic and institution. International Monetary Fund, Washington.

17. Inoue T, Hamori S (2016) Financial access and economic growth: Evidence from Sub-Saharan Africa. Emerg Mark Financ Tr 52: 743-753.

18. Balach R, Law SH, Habibullah MS (2016) The Role of Financial Inclusion in financial development: International evidence. Abasyn J Soc Sci 9: 330-344.

19. Kim J (2016) A Study on the Effect of Financial Inclusion on the Relationship Between Income Inequality and Economic Growth. Emerging Markets Finance and Trade 52: 1-15

20. Kim DW, Yu JS, Hassan MK (2017) Financial inclusion and economic growth in OIC countries.

21. Pradhan RP, Arvin MB, Bahmani S, Bennett SE (2016) Broadband penetration, financial development, and economic growth nexus: Evidence from the Arab league countries. Macroeconomics and Finance in Emerging Market Economies 10: 151-171.

22. Wong YH (2015) Quantifying macroeconomic impacts of financial inclusion.

23. Sethi D, Acharya D (2018) Financial inclusion and economic growth linkage: Some cross-country evidence. J Financ Econ Policy 10: 369-385.

24. Subrahmanyam G, Acharya D (2017) Financial inclusion fosters growth: simple multiplier and 'AK' growth model analysis. Univers J Account Financ 5: 55-59.

25. Demirguc-Kunt $A$, Klapper $L$ (2012) Measuring financial inclusion: The global Findex database. World Bank Policy.

26. Sarma M (2008) Index of Financial Inclusion. ICRIER Working Paper.

27. Aduda J, Kalunda E (2012) Financial Inclusion and Financial Sector Stability with Reference to Kenya: A Review of Literature. J Appl Financ Bank 2: 95-120.

28. Hariharan G, Marktanner M (2012) The growth potential from financial inclusion. Kennesaw State University, pp: 1-22.
29. Sharma D (2016) Nexus between financial inclusion and economic growth: Evidence from the emerging Indian economy. J Financ Econ Policy 8: 13-36.

30. Onaolapo AR (2015) Effects of financial inclusion on the economic growth of Nigeria (1982-2012). Int J Bus Manage Rev 3: 11-28.

31. Migap JP, Okwanya I, Ojeka G (2015) Financial Inclusion for Inclusive Growth The Nigerian Perspective. Int J Inf Technol Bus Manage 37: 1-8.

32. Babajide A, Adegboye FB, Omankhanlen AE (2015) Financial inclusion and economic growth in Nigeria. Int J Econ Financ Issues 5: 629-637.

33. Lenka SK, Sharma R (2017) Does financial inclusion spur economic growth in India? J Dev Area 51: 215-228.

34. Dabla-Norris E, Yan J, Townsend RM, Unsal FD (2015) Financial Deepening, Growth, and Inequality: A Structural Framework for Developing Countries. IMF Working Paper (forthcoming), International Monetary Fund.

35. Omojolaibi JA (2017) Financial Inclusion, governance and economic progress in Nigeria: What happens to the welfare of the poor? Arabian J Business and Management Review 6: 72-85.

36. Brune L, Giné X, Goldberg J, Yang D (2011) Commitments to save: a field experiment in rural Malawi. World Bank Policy Research Working Paper.

37. Angadi VB (2003) Financial infrastructure and economic development: Theory evidence and experience. RBI Occasional Papers 24: 191-223.

38. Neal LD (1990) The rise of financial capitalism: International capital markets in the age of reason. Cambridge, UK: Cambridge University Press.

39. North D (1990) Institutions, institutional change, and economic performance Cambridge University Press, UK.

40. Odedokun MO (1998) Financial intermediation \& economic growth in developing countries. J Econ Stud 25: 203-224.

41. Dev SM (2006) Financial inclusion: Issues and challenges. Economic and Political Weekly, pp: 4310-4313.

42. Beck T, Demirguc-Kunt A, Martinez PM (2007b) Reaching out: access to and use of banking services across countries. J Financial Econ 85: 234-266.

43. Mehrotra N, Puhazhendhi, V, Nair G, Sahoo BB (2009) Financial inclusionan overview. Department of Economic Analysis and Research, National Bank for Agriculture and Rural Development (NABARD), Occasional Paper, pp: 48.

44. Khan HR (2011) Financial Inclusion and Financial Stability: are they two sides of the same coin? Deputy Governor of the Reserve Bank of India.

45. Serrao M, Sequeira AH, Hans BV (2012) Designing a Methodology to Investigate Accessibility and Impact of Financial Inclusion.

46. Ghosh S (2011) Does financial outreach engender economic growth? Evidence from Indian states. Journal of Indian Business Research 3: 74-99.

47. Kendall J, Mylenko N, Ponce A (2010) Measuring Financial Access around the World. Washington: The World Bank.

48. Cumming D, Johan S, Zhang M (2014) The economic impact of entrepreneurship: Comparing international datasets. Corp Gov Int Rev 22 162-178.

49. Swamy V (2010) Financial development and inclusive growth: Impact of government intervention in prioritized credit. Zagreb Int Rev Econ Bus 13: 53 70 .

50. Mohan R (2006) Economic growth, financial deepening, and financial inclusion. Annual Bankers' Conference, Hyderabad.

51. Arora R (2010) Measuring financial access. Discussion Paper in Economics, Griffith University, pp: 1-21.

52. Chattopadhyay SK (2011) Financial inclusion in India: a case-study of West Bengal: RBI. Working Paper Series (DEPR), pp: 1-42.

53. Gupte R, Venkataramani B, Gupta D (2012) Computation of financial inclusion index for India. Procedia-Social and Behavioral Sciences pp:133-149.

54. Dixit R, Ghosh M (2011) Financial inclusion for inclusive growth of India-A study of Indian states. Int J Bus Manage Res 3: 147-156.

55. Barajas A, Chami R, Yousefi SR (2012) The finance and growth nexus reexamined: Do all countries benefit equally? Working Paper IMF.

56. Pearce D (2011) Financial inclusion in the Middle East \& North Africa: Analysis and roadmap recommendations. World Bank Policy Res. 
Citation: Sulong Z, Bakar HO (2018) The Role of Financial Inclusion on Economic Growth: Theoretical and Empirical Literature Review Analysis. J Bus Fin Aff 7: 356. doi: 10.4172/2167-0234.1000356

Page 5 of 5

57. Naceur SB, Samir G (2007) Stock markets, banks, and economic growth: empirical evidence from the MENA region. Res Int Bus Finance 21: 297-315.

58. Moore W, Craigwell R (2003) The relationship between commercial banks interest rates and loan sizes: evidence from a small open economy. Applied Financial Economics 13: 257-266.

59. Natamba B, Mangeni, P, Nakabuye Z, Brendah A, Agasha E (2013) Transaction costs and outreach of microfinance institutions in Uganda. Bus Manage Econ 1: 125-132.
60. Bhattarai K (2015) Financial deepening and economic growth in advanced and emerging economies. Rev Dev Econ 19: 178-195.

61. Arestis P, Demetriades PO, Luintel KB (2001) Financial development and economic growth: the role of stock markets. J Money Credit Bank 33: 16-41.

62. Apergis N, Filippidis I, Economidou C (2007) Financial deepening and economic growth linkages: A panel data analysis. Review of World Economics 143: $179-198$

63. Swamy V (2014) Financial Inclusion, gender dimension, and economic impact on poor households. World Development 56: 1-15. 